\title{
МЕДИЧНА ІНФОРМАЦІЙНА СИСТЕМА МОНІТОРИНГУ СТАНУ ЗДОРОВ'Я НАСЕЛЕННЯ ІЗ ЗАХИСТОМ ПЕРСОНАЛЬНИХ ДАНИХ
}

О. М. Ключко

\author{
Національний авіаційний університет
}

\begin{abstract}
Наведено результати розробки нової медичної інорормаційної системи на основі баз даних для моніторингу ряду показників стану здоров'я населення. Інорормаційна система розроблена нами для моніторингу в часі ряду біохімічних та інших чисельних показників, що характеризують стан організму обстежуваної особи в умовах тих територій українського Полісся, що зазнали екологічного забруднення внаслідок Чорнобильської катастрофри. Система $є$ мережевою, Інтернет-базованою, містить ряд взаємопов'язаних електронних баз упорядкованих даних із відповідним виводом цієї інформації на монітори, в тому числі даних біохімічної лабораторії щодо наявності речовин-забруднювачів довкілля в організмі. Передбачена можливість попереднього автоматизованого аналізу даних, а також захист персональних даних пацієнтів та інших обстежених осіб за допомогою оригінальної розробки електронного апаратного ключа. Наведено інформацію про структуру розробленої системи, її функції та фрункції деяких ії̈ найважливіших блоків, зразки розробленого авторами програмного забезпечення та засобів захисту інформації.
\end{abstract}

Ключові слова: інорормаційна система, моніторинг здоров'я населення, захист персональних даних.

\section{MEDICAL INFORMATION SYSTEM FOR MONITORING OF THE HEALTH STATE OF POPULATION WITH PROTECTION OF PERSONAL DATA}

\section{O. M. Klyuchko}

\section{National Aviation University}

Background. Ecological pollution of Ukrainian Polyssia in result of Chornobyl disaster caused the necessity of public health monitoring at these territories. Development of medical information systems with databases and data protection were supposed to be the good tools for such monitoring organization.

Materials and methods. A set of methods was used for the construction of networked, Internet-based medical information system with databases. Relational database technology was applied; used diagnostic information was in DICOM standard. Software C\# and MySQL were used. For electronic hardware key ATmega8 microcontroller and the scheme that implements the USB interface were used.

Results. Information system was designed for the monitoring in time the numbers of biochemical and other numerical indicators characterizing examined organism state of the person in conditions of territories of Ukrainian Polyssia that were ecologically polluted due to Chornobyl disaster. Developed system is networked, Internet-based; it contains a number of interconnected electronic databases with ordered data and appropriate output of this information on monitors, including biochemical laboratory data about the presence of environmental pollutants in organism. The possibility of preliminary automated data analysis as well as protection of personal data of patients, other surveyed persons was provided due to the development of original electronic hardware key. The information on the structure of developed system, its functions as well as functions of some of its most important blocks, samples of software developed by the authors and means of information protection in such system was given.

Conclusion. Results of the development of new medical information system based on databases with for monitoring of numerical indicators of public health were presented. Data protection in this information system was realized using original electronic hardware key.

Key words: information system, monitoring, public health, personal data protection. 


\title{
МЕДИЦИНСКАЯ ИНФОРМАЦИОННАЯ СИСТЕМА ДЛЯ МОНИТОРИНГА СОСТОЯНИЯ ЗДОРОВЬЯ НАСЕЛЕНИЯ С ЗАЩИТОЙ ПЕРСОНАЛЬНЫХ ДАННЫХ
}

Е. М. Ключко

\author{
Национальный авиационный университет
}

\begin{abstract}
Представлены результаты разработки новой медицинской информационной системы на основе баз данных, для мониторинга ряда показателей состояния здоровья населения. Информационная система была разработана нами для мониторинга во времени ряда биохимических и других показателей в численном виде, характеризующих состояние организма обследуемого лица в условиях территорий украинского Полесья, которые подверглись экологическому загрязнению вследствие Чернобыльской катастрофы. Система является сетевой, Интернет-базированной, содержит ряд взаимосвязанных электронных баз упорядоченных данных с соответствующим выводом информации на мониторы, в том числе данных биохимической лаборатории о наличии веществ-загрязнителей окружающей среды в организме. Предусмотрена возможность предварительного автоматизированного анализа данных, а также защита персональных данных пациентов и других обследуемых лиц с помощью оригинальной разработки электронного аппаратного ключа. Приведена инорормация о структуре разработанной системы, ее фрункциях и фрункциях некоторых ее важнейших блоков, образцы разработанного авторами программного обеспечения и средств защиты инорормации.
\end{abstract}

Ключевые слова: информационная система, мониторинг здоровья населения, защита персональных данных. 
Вступ. У попередніх публікаціях [1, 2, 3] автором представлено деякі теоретичні принципи створення технічних електронних інформаційних систем для медицини та біології, а також досвід ряду практичних розробок таких систем. Наступним кроком стало застосування розроблених елементів систем із використанням інформаційно-комп'ютерних технологій (IKT) для створення електронних технічних систем моніторингу довкілля [1, 2], зокрема системи, названої нами «ЕкоIC». Перша версія «ЕкоIC» описана в публікації [4]. Будучи складною мережевою системою, що допускає вдосконалення та відносно незалежний розвиток окремих її частин, на певному етапі було вирішено розширити можливості системи «ЕкоIС», додавши медичну підсистему, суть структури та функціонування якого описана нижче. Це $є$ особливо цінним для умов українського Полісся, екологічні умови якого в багатьох районах були погіршені внаслідок їхнього забруднення поллутантами внаслідок Чорнобильської аварії (1986р.). Тому вбачали за доцільне розширити функціональні можливості розробленої нами інформаційної системи $з$ тим, щоб виконувати моніторинг не тільки наявності поллутантів у довкіллі та реакцію на них біологічних організмів, але й моніторинг у часі ряду показників здоров'я людини, в тому числі біохімічних показників функціонування організму.

Практика сучасного життя показала, що при переході вітчизняних медиків до роботи на новітніх електронних комплексах для моніторингу здоров'я населення, яке проживає в несприятливих екологічних умовах, необхідно створення та впровадження локальних інформаційних систем (IC) діагностичних центрів, окремих лікарів, формування єдиних і в той же час гнучких форматів зберігання діагностичних даних із наступним об’єднанням таких індивідуальних робочих місць в єдині мережі, спочатку - рівня клінічної установи, потім вищого рівня, аж до загальнодержавного. Також у сучасних умовах значної ваги набуває проблема захисту персональних даних. Система захисту персональних даних повинна бути надійною, ефективною та одночасно простою для застосування як самим пацієнтом, так і уповноваженим лікарем. Ефективність медичної IC багато в чому залежить як від максимально можливої формалізації діагностичної інформації, так і від удалих розробок програмного забезпечення відповідного комп’ютеризованого обладнання, для яких потрібна активна співпраця медиків та інженеріврозробників [1].
Мета роботи: представлення розробленої автором медичної електронно-інформаційної системи для моніторингу ряду медичних показників стану здоров'я населення, біохімічних показників організму, електронної медичної картки пацієнта тощо для районів українського Полісся, інших екологічно забруднених територій та адекватного способу захисту інформації у такій системі - за допомогою апаратного електронного ключа.

Матеріал і методи досліджень. Набір методів було застосовано для побудови мережевої, Інтернет-базованої медичної інформаційної системи з базами даних. Застосовано технологію реляційних баз даних, приладова діагностична інформація - у стандарті DICOM. Використано програмне забезпечення C\# та MySQL. Для виконання електронного апаратного ключа використовували мікроконтролер ATmega8 та схему, що реалізує USB інтерфейс.

Результати та їх обговорення. Автоматизація діагностики, скринінг-фільтрація даних. У ході обгрунтування виконаних робіт можна відзначити актуальність автоматизації діагностики [1]. Одним із таких додатків у функціях IC є скринінг-фільтрація за деяким набором діагностичних параметрів пацієнтів при масовому обстеженні та виділенні групи ризику для проведення більш повного обстеження. При цьому вважається, що іноді може бути не потрібним досягнення високої достовірності первинної діагностики, оскільки поріг відбору може бути заданий із достатнім запасом, проте дані потребуватимуть певної математичної обробки [1, $5,6]$. Для скринінгу можуть використовуватися відносно прості алгоритми типу дерева ознак або розрахунку деякої вагової метрики вхідних параметрів [5]. Більш складні діагностичні програми - експертні системи - спираються на певну базу знань, що формується накопиченням досвіду з застосування інших методів діагностики. Вони використовують складні алгоритми, засновані на аналізі зв'язків між ознаками або спираються на моделі нейронних мереж, які можуть самоналаштовуватися за деякою навчальною вибіркою, що робить їх практично універсальними $[1,5,6]$. Для отримання об’єктивної діагностичної інформації може використовуватися текстурний аналіз томограм або ультразвукових зображень, автоматичне виділення об'єктів, визначення характеристик із подальшою їх ідентифікацією та класифікація за допомогою систем розпізнавання образів $[1,5,6]$. У подальшому оперування з такими даними потребує 
застосування IC на зразок уже розроблених прототипів [1, 5-10], у тому числі з експертними системами $[4,7]$ та автоматизованими електронними робочими місцями [8].

Такі системи комп’ютерної діагностики можуть використовуватися як спільно з IC типу електронної історії хвороби, так і автономно, наприклад безпосередньо в діагностичних центрах або в кабінетах прийому профільних лікарів. Спільно 3 діагностичним обладнанням можуть використовуватися також спеціальні прикладні програми, оптимізовані під вузьке використання - налаштування оптимальної візуалізації, побудова довільних зрізів або проекцій, тривимірне моделювання, суміщення зображень, форматування груп зображень для друку [1]. Все це позбавляє лікарів-діагностів і допоміжний персонал від рутинних операцій, значно спрощує, полегшує та прискорює їхню роботу. Протягом останнього десятиліття в Україні такі програмні продукти стали активно розробляти та впроваджувати [1, 7-10].

Створення електронної медичної картки пацієнта. Опишемо, що являє собою у наших роботах електронна медична картка обстежуваної особи, i що вона дає для лікаря. Таким варіантом медичної карти є підсистема IC, що спирається на технологію реляційних баз даних (БД). Реляційна база даних - деяка таблиця (або декілька пов'язаних таблиць), в якій зберігається довільна кількість записів - чітко структурованих рядків даних. Такий спосіб зберігання інформації дозволяє зручно, в автоматичному режимі, відбирати дані за деякою ознакою або набору ознак, впорядковувати їх відображення по різних стовпцях таблиці, наприклад, за датою, прізвища, діагнозу. Ця технологія дозволяє накопичувати та зберігати інформацію, здійснювати її швидкий пошук. Подібні IC системи активно використовуються в управлінні виробництвом, банківській справі, інших областях. Сучасні засоби розроблення прикладних програм дозволяють поєднати БД із функціями додаткового оброблення даних — розраховувати статистичні параметри, будувати діаграми, спрощувати створення звітів [1].

При роботі з медичною інформацією така IC відноситься не до певного пацієнта, а до широкої групи (рівень клінічного закладу, району, міста, країни). Отже, медичній карті пацієнта відповідає вибірка із загальної БД відповідного рівня за ознакою даного пацієнта. Електронна форма медичної карти полегшує вирішення багатьох завдань: а) документування (накопичення, надійне зберігання, можливість зручного перегляду) довільної медичної інформації про пацієнта з прив’язкою до календарної дати та особи пацієнта;

б) пошук (фільтрацію по набору ознак) необхідної інформації;

в) відстеження тимчасової залежності окремих діагностичних параметрів;

г) дослідження ефективності роботи - відстеження кореляції окремих залежностей для пацієнта, формування інтегральних статистичних залежностей рівня закладу охорони здоров’я тощо.

Природно, така IC система передбачає наявність зручних засобів введення та відображення інформації. Для введення текстової і цифрової інформації надаються форми (бланки), що відображаються на екрані комп’ютера [1]. При можливості формалізації даних (формування кінцевого або доповнюваного списку значень вводиться параметра) вибір значення робиться з наданого списку. В систему можуть додаватися всілякі електронні довідники (класифікатор діагнозів, лікарських засобів, адресна книга тощо). Передбачаються кошти імпорту даних апаратних обстежень. Багато сучасних медичних приладів (томографи, флюорографи, ультразвукові сканери, кардіографи тощо) формують результат безпосередньо в електронному вигляді. Існують міжнародні стандарти для приладової діагностичної інформації, наприклад DICOM. Для захисту даних від випадкової втрати в результаті аварії устаткування або навмисного злому сховища даних такі IC розміщуються на добре захищених серверах, що мають засоби резервного копіювання даних [1].

При роботі з розробленою нами IC лікар може досить швидко вводити нову інформацію (природно при відповідної кваліфікації роботи з клавіатурою), їі систематизувати у вигляді таблиць i графіків, порівняти наявний випадок із подібними для уточнення діагнозу та оцінювання перспектив розвитку стану пацієнта, швидко складати звіти та виписки, значна частина текстів яких може формуватися автоматично та методом копіювання. При глобалізації такої системи, крім наявної виписки лікар може отримати швидкий доступ безпосередньо до діагностичної інформації. В умовах нашої країни тільки деякі заклади охорони здоров’я (303) мають локальні комп’ютерні мережі та вихід в Інтернет, причому навіть у цьому випадку кількість комп’ютерів явно недостатня, пряме перенесення західних розробок (і навіть стандартів) на умови України часто неможливе. $Є$ проблеми 
роботи зі слов'янським алфавітом, необхідність переналаштування, структуризації даних. Тому виконання таких робіт в Україні вимагає активної роботи фахівців як у галузі медицини, так і IKT.

Розробка програмного комплексу «Загальна медична база даних» у складі електронної інформаційної системи «ЕкоIC». Розроблено медичну IC із БД пацієнтів і всіх мешканців для застосування в екологічно забруднених районах українського Полісся (зокрема, м. Новоград-Волинський та його околиць), що може бути застосована для проведення моніторингу характеристик стану здоров'я населення, яке проживає в екологічно несприятливому довкіллі аеропортів. IC названа нами «Загальна медична база даних». При розробці IC ураховували дві важливі особливості поліського регіону. Перша — це райони, що зазнали радіаційного забруднення внаслідок Чорнобильської аварії, і в таких районах надзвичайно важливим $є$ проводити багаторічні моніторинги як екологічної ситуації, так і стану здоров'я населення для підтримання цього стану на максимально високому рівні та своєчасного реагування на показники захворюваності та смертності. Друга - регіон характеризується великою кількістю лісів, малою щільністю населення, яке проживає у віддалених важкодоступних малих населених пунктах. У таких умовах є проблематичною не тільки швидка медична допомога та медична допомога взагалі, але навіть і просто зв'язок між населеними пунктами. Сучасні IКТ допомагають досягти кардинальних успіхів у вирішенні таких завдань [1].
Розроблено мережеву IC із застосуванням БД для медичного обслуговування населення та моніторингу його стану здоров'я, в якій найбільш детально розроблено такі елементи:

1 - медичні бази даних;

2 - електронна медична картка пацієнта;

3 - електронний ключ для захисту електронної інформації стану здоров'я пацієнта, оскільки така інформація є конфіденційною.

Далі наведемо інформацію про виконання кожного елементу IC.

Розробка електронної медичної бази даних. Електронна медична база даних - електронний аналог звичайної медичної карти пацієнта. Це сховище записів, кожна з яких містить інформацію медичного характеру: скарги, діагноз, назначені лікарські засоби, результати лабораторних досліджень, медичні показники тощо. Кожен запис може містити як текстову інформацію та табличні дані, так і графічні зображення, а також прикладені файли довільного типу (електронні таблиці, документи у форматі PDF тощо). Крім того, записи можуть містити медичні зображення формату DICOM (KT, MPT, УЗД тощо). Створена електронна медична БД доступною у будь-якому $3 О 3$ України, де $є$ Інтернет. Вона виключає втрату даних і необхідність пам'ятати, де яка довідка знаходиться.

В ході написання коду для електронної медичної бази даних спочатку був розроблений інтерфейс програми, що включає близько 20 форм. Структура взаємодії між формами наведена на рис. 1.

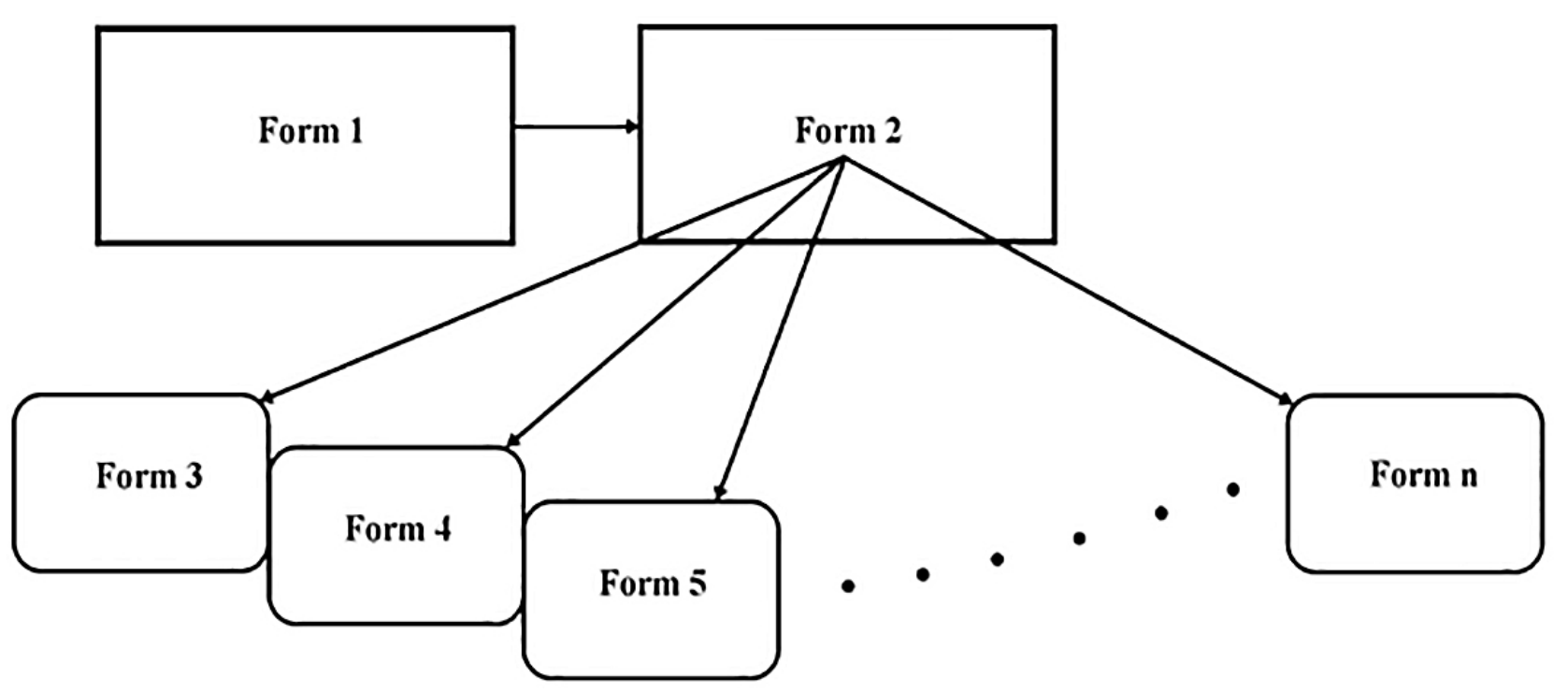

Рис. 1. Структура програмного комплексу «Загальна медична база даних» 
Form1 - інтерфейс «вітання», а також виконує функцію входу в основну програму із зчитуванням даних електронного ключа та ідентифікаційного номера пацієнта, якщо він вже внесений у базу.

Ha Form2 зображено декілька вкладок відповідно до рівня доступу лікаря на цінності інформації. Наприклад, лікар-рентгенолог не зможе побачити історію пацієнта в інфекційному відділенні. На першій вкладці зображено дані пацієнта. Якщо електронний ключ із рівнем доступу «реєстратура» (рис. 2), то користувач може додавати, або редагувати персональні дані пацієнта. Інші лікарі бачать тільки інформацію без можливості редагування.

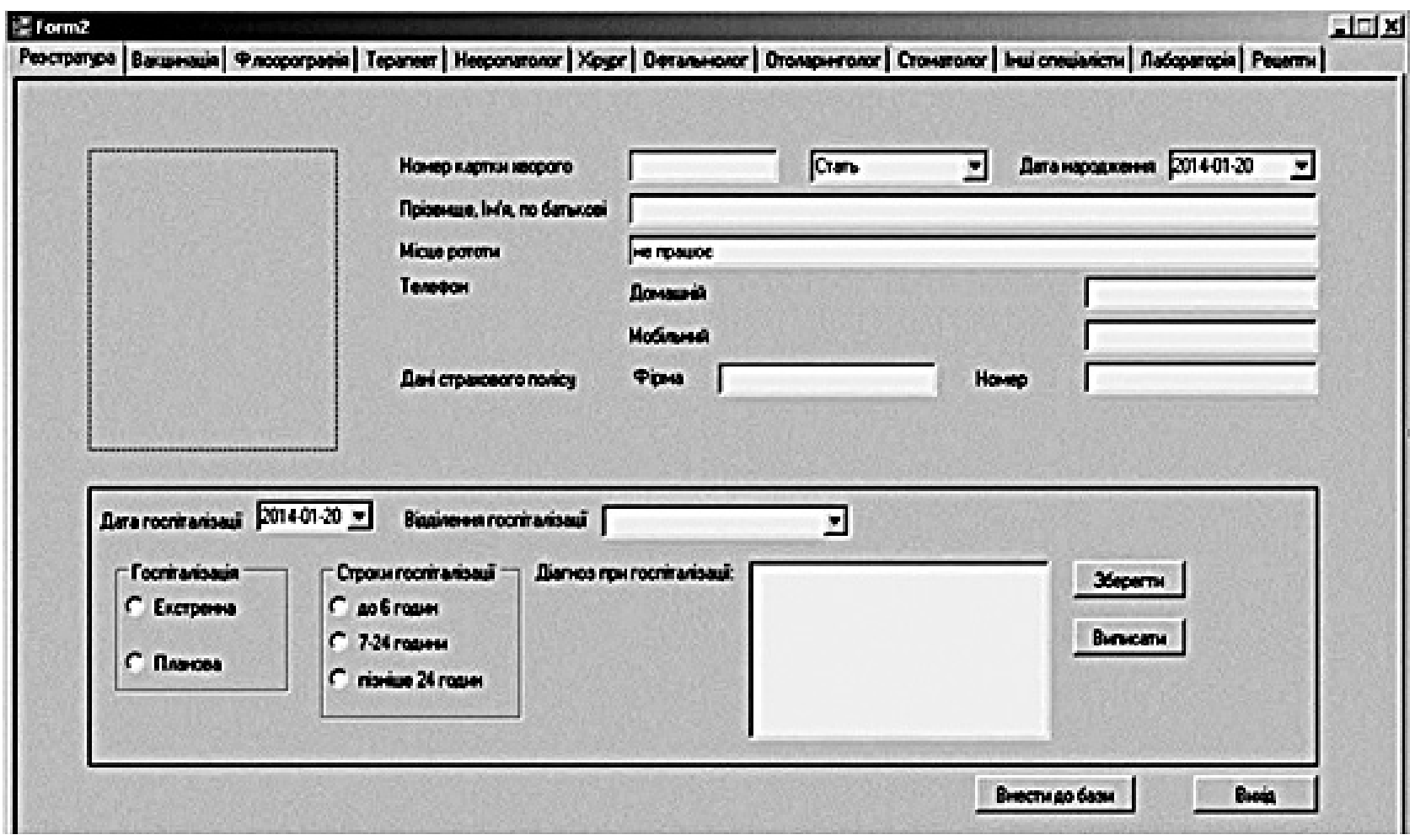

Рис. 2. Form2, вкладка «Реєстратура»

На інших вкладках знаходяться автоматизовані робочі місця (АРМ) відповідних лікарів, що відрізняються від описаних вище ЕРМ як функціонально, так і програмним забезпеченням. Лікар у кожну хвилину з АРМ може відкрити історію хвороби та переглянути ії. Пошук відбувається по даті внесення до БД.

На вкладці «Лабораторія» знаходиться декілька кнопок, що викликають відповідні форми для збереження або переглядання результатів аналізів (рис. 3, 4).

Опис таблиць MySQL та взаємодія C\# з базою даних. Іноді буває необхідним зв'язати між собою ці, здавалося б, різні в усьому технології: наприклад, для написання оффлайнового клієнта для CMS [1], що працює на MySQL, створення локальної БД/програми, що використовує її без обмежень продуктивності, внесених, наприклад, безкоштовною версією Microsoft SQL. Нами використано програми Navicat8.1 for MySQL для спрощення роботи з MySQL - безкоштовні версії Freeware. Звичайно, її можна цілком замінити на MySQL Command Line Client. У статті приклади коду наведено рідною мовою NET - C\#.

На сайті MySQL - доволі ретельно описано процес встановлення програмного забезпечення (П3): ставимо студію, MySQL, після чого ставимо MySQL.NETConnector. Даля необхідно створити проєкт, що зможе використовувати класи MySQL Connector для роботи з БД. Запускаємо студію, створюємо новий проєкт - Windows. Forms, мова C\#. Після цього, додаємо Reference на компонент Mysql.Data. Тепер доступний простір імен Mysql.Data. 3 нього будемо використовувати MySql.Data.MySqlClient додаючи відповідну директиву using.

В лістингу «3'єднання» показано, як правильно писати код, щоб з'єднатися з базою даних. 


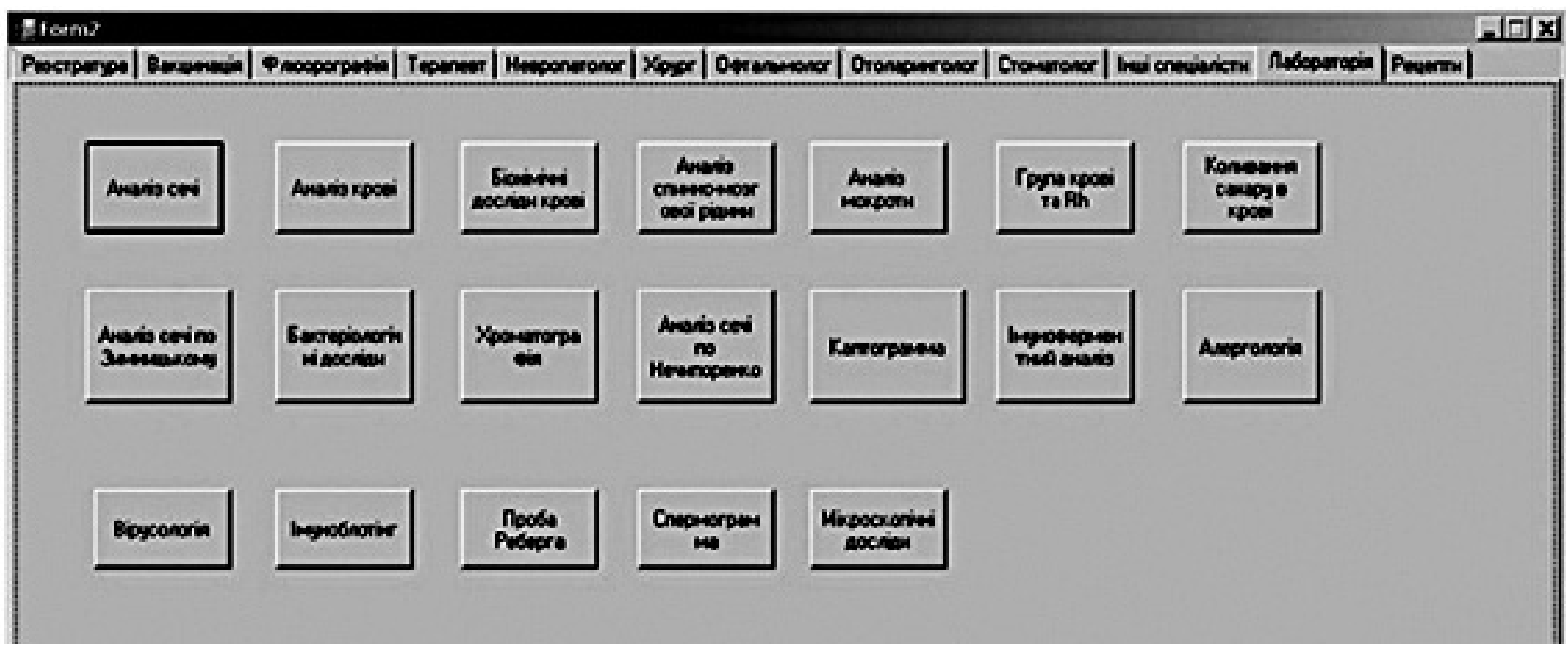

Рис. 3. Form3, вкладка «Лабораторія»

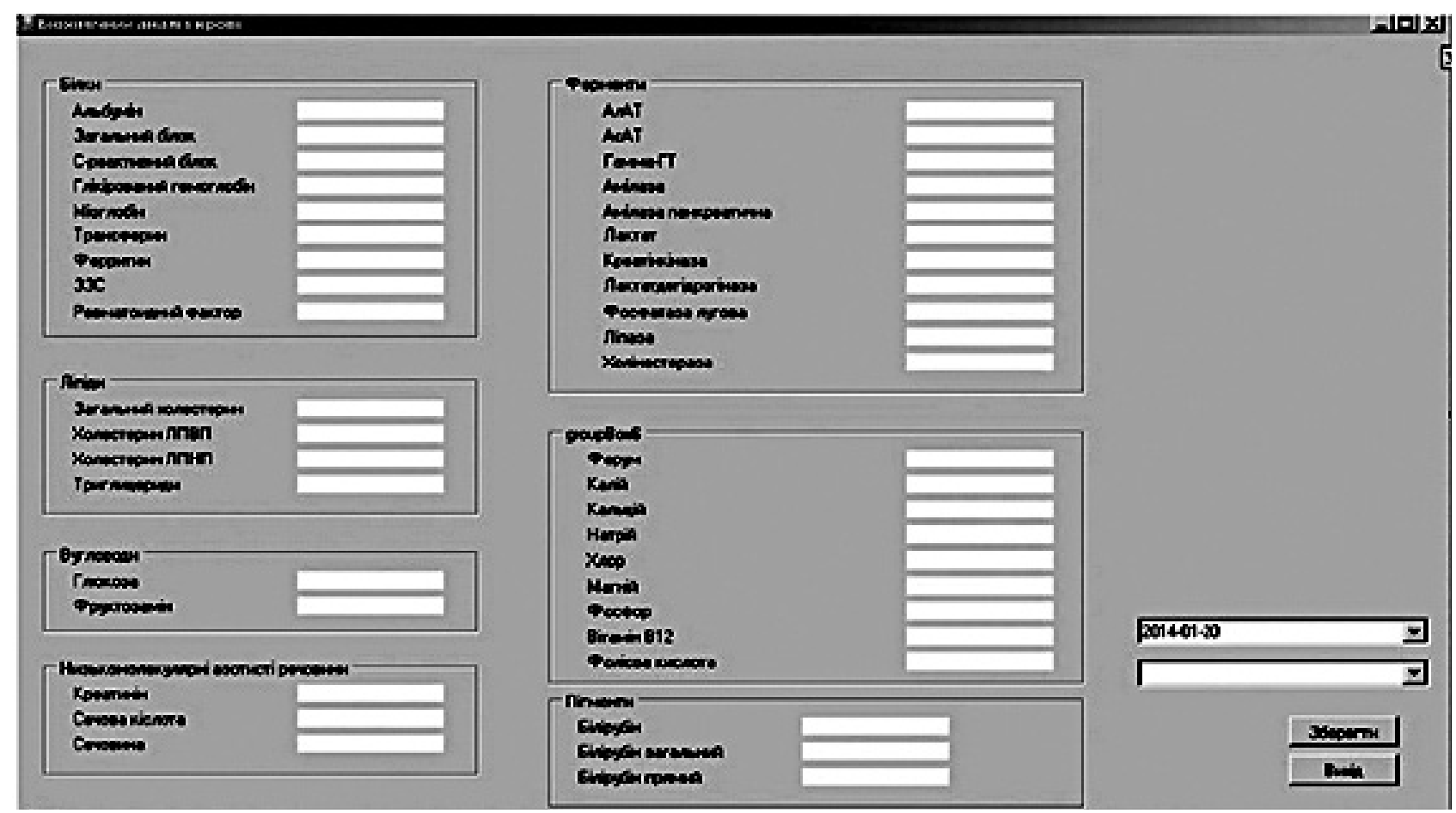

Рис. 4. Form5, «Біохімічний аналіз крові»

\section{Лістинг програми «З'єднання»:}

// дані з’єднання

string MySQL_host = «localhost»;

string MySQL_port = «3306»;

string MySQL_uid = «root»;

string MySQL_pw $=$ «nopassword»;

MySqlConnection Connection = new MySqlConnection( «Data Source=» + MySQL_host + «;Port=»+ MySQL_port + «;User Id=» + MySQL_uid + «;Password=» + MySQL_pw + «;»);

MySqlCommand Query = new MySqlCommand();
Query.Connection = Connection;

try

\{

Console.WriteLine(«3’єднуюсь з сервером бази даних»);

Connection.Open();

\}

catch (MySqlException SSDB_Exception)

\{

Console.WriteLine(«Перевірте налаштування сервера!!n: «+ SSDB_Exception.Message); 
return;

\}

Console. WriteLine(«OK»).

Для збереження інформації та її подальшого пошуку звичайно потрібно створювати базу даних у таблицях, саме тому була використана найвідоміша СУБД, якою користується 60-70 \% усього світу - MySQL. У процесі програмування створено такі таблиці — «Patient», «Doctor», «Hospital», «AccessLevel» та інші (на кожну вкладку програми та форму). В таблиці «Patient» зберігається інформація про пацієнта загального користування (ПІП/б., домашня адреса, телефон, інші контактні дані, час госпіталізації, відділ направлення), а також його ID, по якому відбувається пошук у базі даних відповідно до історії хвороби. У таблиці «Hospital», знаходяться дані про 303 (ЕДРПОУ, контактні дані приймальні та головного лікаря), де працює лікар, який вносить свої дані до БД.
Розробка електронного апаратного ключа для захисту медичних даних в «ЕкоIC». Для захисту персональних даних обстежуваної особи в IC було застосовано такий метод як захист програми за допомогою апаратного ключа. За допомогою цього методу захищено конфіденційну інформацію про здоров’я пацієнта. Особливо необхідність захисту такої конфіденційної інформації постає у випадку багаторічних моніторингів показників здоров'я великої кількості населення в екологічно несприятливих регіонах (рис. 5).

Необхідно підкреслити простоту застосування людиною такого способу захисту даних: відповідна інформація візуалізується на екрані монітора тільки у тому випадку, якщо пацієнт або його лікар вставлять у блок комп’ютера персональний електронний ключ-код, зовні схожий на флеш-пам’ять. Багато спеціалізованих пакетів програм використовують цей метод апаратного ключа, проте наш метод також містить елементи новизни.

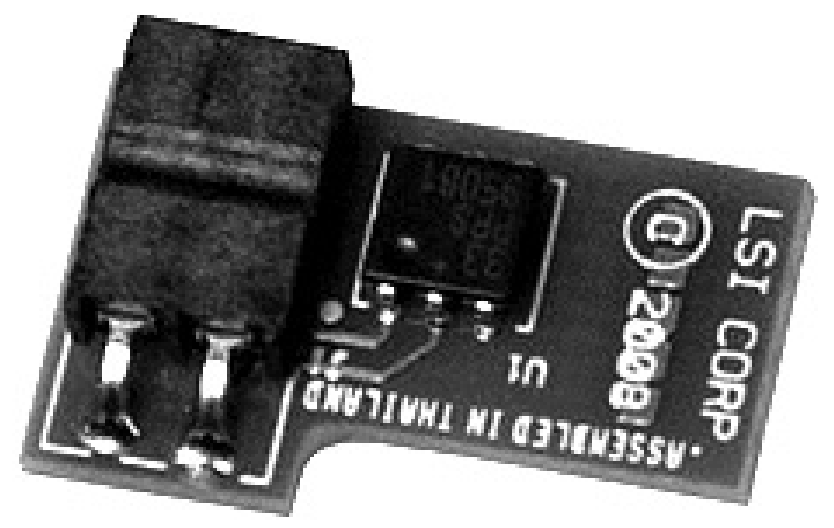

Рис. 5. Апаратний ключ

Існує декілька переваг застосування такого способу захисту в порівнянні з іншими, наприклад, програмним захистом. По-перше, апаратний ключ — це фізичний пристрій та, в ідеалі, щоб запустити програму більш ніж на одному ПК, знадобиться та сама кількість апаратних ключів, отже це прямий захист від копіювання програм. По-друге, апаратний ключ — це мікросхема, в якій знаходиться певна інформація, дістатися до якої неможливо (окрім як програмно), тому що неможливо заглянути в середину такого «чорного ящика». Частіше за все в апаратному ключі встановлена не фізична пам’ять, а мікроконтролер, що працює за суворою програмою, «вшитою в нього». Крім того, після запису такої програми в мікроконтролер, можливо «наказати» йому захистити цю ж програму — проставити ф’юз при прошивці на «тільки читання», що ніякими впливами вже не зняти (тільки затерти всю інформацію з ключа при цьому також втратити алгоритм його роботи).

Кроками до створення оригінального електронного ключа стали такі (рис. 6, 7). Очевидно, що потрібні мікроконтролер і схема, яка реалізує USB інтерфейс. Для нашого проєкту використовували мікроконтролери Atmega, оскільки вони мають доступне безкоштовне програмне забезпечення для прошивки, а також низьку ціну в порівнянні зі своїми аналогами.

Конкретно для запропонованого автором ключа обрано мікроконтролер ATmega8, оскільки він не включає в себе внутрішнього функціоналу USB, що був реалізований самостійно. Обраний варіант корпусу - TQFP, що можна пропаяти руками. TQFP корпус відноситься до розряду SMD компонентів 

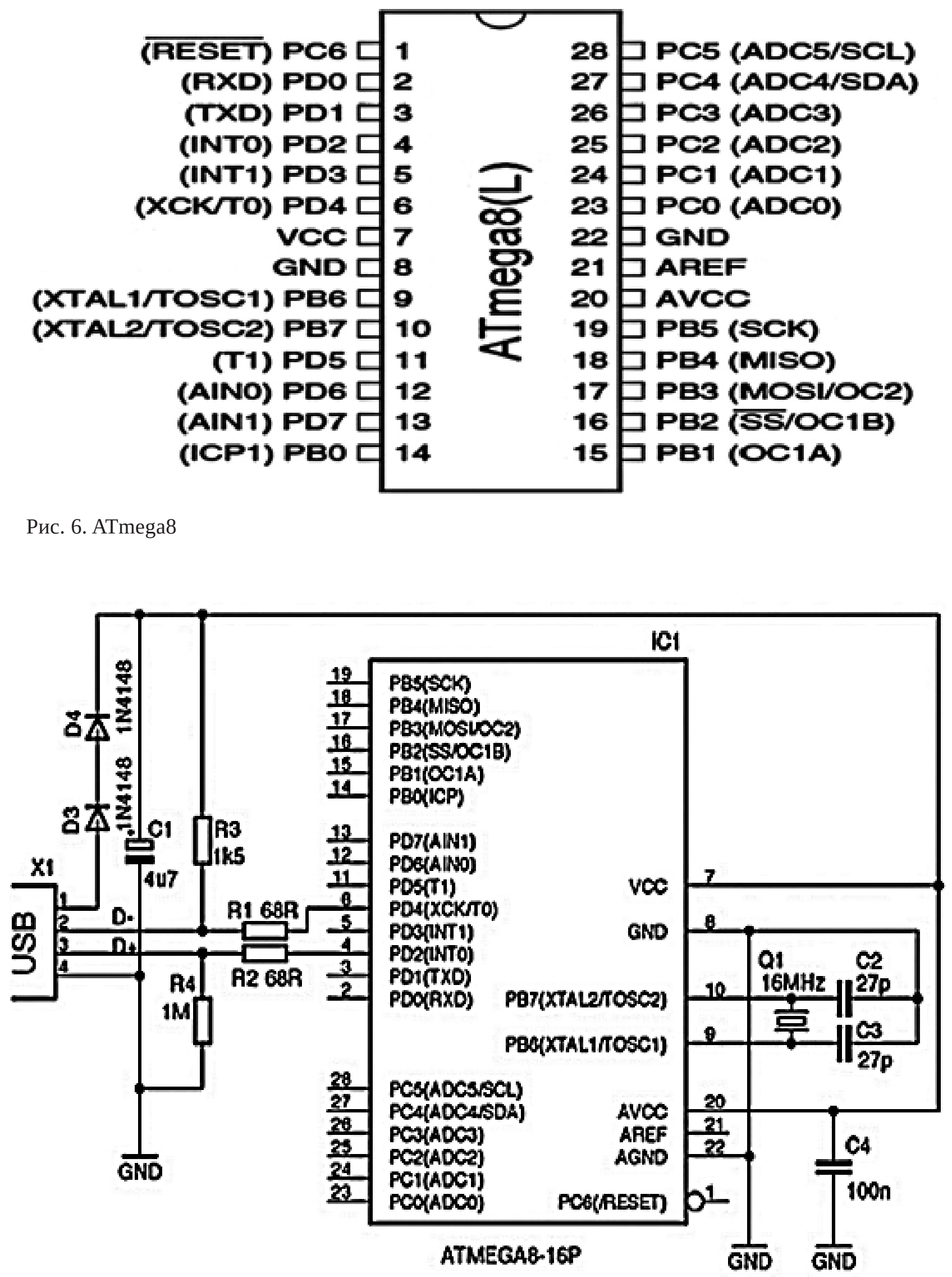

Рис. 7. Принципова схема апаратного ключа 
— компонентів поверхового монтажу. Це в свою чергу означає, що деталь встановлюється прямо на печатній платі без отворів для ніжок.

Флеш-пам'ять програм. Команда контролера займає 16 або 32 біта, тому флеш-пам'ять програм організована у вигляді масиву 4K 16-ти бітових слів. Флеш-пам’ять розділена на дві секції — область додатків і область завантаження (що знаходиться в старших адресах ). Флеш-пам’ять витримує до 10000 циклів перезапису.

Організація оперативної пам'яті. Молодші 1120 адрес адресують регістри АЛУ, регістри введення/ виводу й оперативну пам'ять. Перші 96 адрес ставляться до регістрів введення/виводу, решта 1024 байти - пам’ять.

Додатково існує електрично програмована пам’ять, що містить 512 байт і витримує 100000 циклів перезапису. Доступ до пам'яті здійснюється через спеціальні регістри введення/виводу.

Таймери. 0-й таймер загального призначення має 8-бітовий лічильник, із 10-бітовим додатковим дільником частоти. Таймер може генерувати переривання по переповненню або по досягненню значення.

1-й таймер має 16- бітовий лічильник. Він може бути використаний для генерації сигналів із змінною шпаруватістю (широтно модульовані імпульси, генерації частоти та визначення часу надходження зовнішніх подій). Два регістри порівняння значення таймера можуть використовуватися для генерації імпульсів із змінною шпаруватістю. Вхідний регістр використовується для завантаження значення таймера в момент надходження зовнішньої події.

2-й таймер є 8-ми бітним, і може генерувати частоту та сигнали зі змінною шпаруватістю, генерувати переривання по переповненню та досягненню значення.

Послідовний периферійний інтерфейс. Особливості інтерфейсу:

* Дуплексна передача;

* Операції в режимах задатчика/виконавця;

* Програмовані режими передачі: перший або старший або молодший біт;

* 7 швидкостей передачі;

* Генерація переривань.

Універсальний синхронно-асинхронний передавач.

Принципова схема електронного апаратного ключа та код. Нами використано вже існуючу розробку V-USB, потрібно було зібрати тільки схему. Схема доволі проста та включає в себе USBштекер,
MK ATMEGA8, 2 діода для зменшення напруги на мікроконтролер оскільки USB дає напругу в 5В. Для правильної роботи мікроконтролера при 16МГц на ніжки МК повинно подаватися 3,3В. Для роботи ключа потрібно 4 резистори та 3 конденсатори. Також потрібно прошити мікропроцесор відповідною програмою. В лістингу показано як відправляти дані, що вшиті в оперативну пам’ять мікроконтроллера [1].

\section{Лістинг програми відправки даних:}

uchar usbFunctionRead(uchar *data, uchar len) \{

if(len $>$ bytesRemaining)

len = bytesRemaining;

eeprom_read_block(data, (uchar $*) 0$ + currentAddress, len);

currentAddress += len;

bytesRemaining $-=$ len;

return len;

\}

В основній програмі на ПК повинен бути написаний такий код для прочитання інформації 3 мікроконтролера:

My UsbDevice = UsbDevice. OpenUsbDevice(MyUsbFinder);

if (MyUsbDevice $==$ null) throw new Exception(«Device Not Found.»);

IUsbDevice wholeUsbDevice $=$ MyUsbDevice as IUsbDevice;

if (!ReferenceEquals(wholeUsbDevice, null)) \{

wholeUsbDevice.SetConfiguration(1); wholeUsbDevice.ClaimInterface(0); \}

UsbEndpointReader reader $=$ MyUsbDevice. Open

EndpointReader(ReadEndpointID.Ep01);

byte[] readBuffer = new byte[1024];

while (ec $==$ ErrorCode. None)

\{

int bytesRead;

ec = reader.Read(readBuffer, 5000, out bytesRead); if (bytesRead $==0$ ) throw new Exception(string.

Format $(«\{0\}$ :No more bytes!», ec));

Console. WriteLine( «\{0\} bytes read», bytesRead);

Console.Write (Encoding. Default.

GetString(readBuffer, 0, bytesRead));

\}

Console.WriteLine( «\r\nDone! $\backslash r \backslash n »)$.

Якщо інформація від мікроконтролера не приходила протягом 5 секунд, то вважалося, що вся інформація прийнята. 
Висновки. 1. Виконано всебічний аналіз зразків TIC на основі БД, що створені на сьогоднішній день для робіт у галузі екології біооб’єктів (у тому числі в екстремальних умовах), визначено пріоритетні напрями власних робіт. Отримані результати зіставлені з іншими методами та вже існуючими зразками тIC з метою кращого вибору стратегії створення системи для широкомасштабного екологічного моніторингу «ЕкоIC» $[1,4]$.

2. Під час розробки електронної системи захисту програмного комплексу «Загальна медична база даних» у складі «ЕкоIC» розроблено власну оригінальну програму на основі СУБД та її захист за допомогою апаратного ключа на основі мікроконтролера AVR ATmega8.

3. Показано блок схему взаємодій форм програми «Загальна медична база даних» та роз’яснено зв’язування мови С\# та системи управління базами даних MySQL за допомогою MySQL Connector.

4. Представлено основні етапи проектування апаратного ключа, застосованого для захисту персональних медичних даних у БД, його електрична схема та програмне забезпечення за допомогою середовища програмування AVR Studio. Роз'яснено зв'язування електронного ключа з програмним комплексом за допомогою бібліотеки LibUSBdotNET (бібліотека стала стандартною в мовах програмування С та $\mathrm{C}++)$.

\section{Література.}

1. Ключко О. М. Інформаційно-комп’ютерні технології в біології та медицині / О. М. Ключко. — К. : Вид-во HAУ, 2008. - 252 c.

2. Plakhotnij S. A. Information support for automatic industrial environment monitoring systems / S. A. Plakhotnij, O. M. Klyuchko, M. V. Krotinova // Electr. Contr. Syst. — 2016. — Vol. 47. — № 1. — P. 19-34.

3. Klyuchko O. M. The set of program models for ecological monitoring technical system based on principles of biophysics / O. M. Klyuchko, V. N. Shutko, D. O. Navrotskyi, A. M. Mikolushko // Electr. Contr. Syst. 2014. - Vol. 42. — № 4. - P. 135-142.

4. Klyuchko O. M. Computer recognition of chemical substances based on their electrophysiological characteristics / O. M. Klyuchko, A. Ya. Biletsky // Biotechnol. Acta. — 2019. — Vol. 12. — № 5. P. 5-28.

5. Klyuchko O. M. On the mathematical methods in biology and medicine // Biotechnol. Acta. - 2017. — Vol. 10. — № 3. - P. 31-40.
5. У розроблених БД можуть зберігатися всі виписані рецепти, підробка яких неможлива, а, отже, вся інформація може бути перевірена.

6. Для даного проєкту застосовано майже десяток прикладних програм. Реалізовано основну програму під Windows 8 на платформі .NET Framework 4.5. Розроблену програму, в тому числі, можна встановлювати на планшети та використовувати зв’язок із базою даних у віддалених від 303 місцях.

7. Запропоновано застосування методів комп’ютерного моделювання для оцінювання складних тIC, а також малодосліджених об’єктів (гКРК) у ситуаціях, коли використання традиційних методологій або ускладнене, або занадто дороге.

8. Запропоновано методи екомоніторингу стану здоров’я населення на забруднених поллутантами землях українського Полісся з використанням системи «ЕкоIC».

На завершення автор зазначає необхідність подальшого створення електронних IC на основі БД для медичної галузі з урахуванням ї̈ специфіки та медико-біологічних об’єктів. Власне, описана медична інформаційна система з захистом персональних даних - один із можливих прикладів застосування IKT для потреб сучасної медицини, співавторства в таких роботах медиків та інженерів, а також ствердження необхідності та важливості подальшої інформатизації галузі охорони здоров’ я.

6. Klyuchko O. M. Some trends in mathematical modeling for biotechnology / O. M. Klyuchko, Yu. M. Onopchuk // Biotechnol. Acta. — 2018. — Vol. 11. — № 1. P. 39-57.

7. Klyuchko O. M. Expert system for biology and medicine / O. M. Klyuchko // Biotechnol. Acta. — 2018. — Vol. 11. — № 5. - P. 5-28.

8. Klyuchko O. M. Electronic automated work places for biological investigations / O. M. Klyuchko, N. I. Aralova, A. A. Aralova // Biotechnol. Acta. - 2019. — Vol. 12. — № 2. - P. 5-26.

9. Klyuchko O. M. Fish information databases construction: data preparation and object-oriented system analysis / O. M. Klyuchko, L. P. Buchatsky, O. V. Melezhyk // Fishery sciences of Ukraine. - 2019. - Vol. 49. № 3. - - P. 32-47.

10. Klyuchko O. M. Creation of fish databases for electronic interactive map: tables and keys / O. M. Klyuchko, L. P. Buchatsky, Yu. P. Rud, O. V. Melezhyk // Fishery sciences of Ukraine. — 2019. — Vol. 50. — № 4. — P. 37-57. 


\section{References.}

1. Klyuchko, O. M. (2008). Information and computer technologies in biology and medicine. Kyiv: NAU-druk. [In Ukrainian].

2. Plakhotnij, S. A., Klyuchko, O. M., Krotinova, M. V. (2016). Information support for automatic industrial environment monitoring systems. Electr. Contr. Syst., 1 (47), 19-34.

3. Klyuchko, O. M., Shutko, V. N., Navrotskyi, D. O., Mikolushko, A. M. (2014). The set of program models for ecological monitoring technical system based on principles of biophysics. Electr. Contr. Syst., 4 (42), 135-142.

4. Klyuchko, O. M., Biletsky, A. Ya. (2019). Computer recognition of chemical substances based on their electrophysiological characteristics. Biotechnol. acta., 12 (5), 5-28.

5. Klyuchko, O. M. (2017). On the mathematical methods in biology and medicine. Biotechnol. acta., 10 (3), 31-40.
6. Klyuchko, O. M., Onopchuk, Yu. M. (2018). Some trends in mathematical modeling for biotechnology. Biotechnol. acta., 11 (1), 39-57.

7. Klyuchko, O. M. (2018). Expert system for biology and medicine. Biotechnol. acta., 11 (5), 5-28.

8. Klyuchko, O. M., Aralova, N. I., Aralova, A. A. (2019). Electronic automated work places for biological investigations. Biotechnol. acta., 12 (2), 5-26.

9. Klyuchko, O. M., Buchatsky, L. P., Melezhyk, O. V. (2019). Fish information databases construction: data preparation and object-oriented system analysis. Fishery sciences of Ukraine, 49 (3), 32-47.

10. Klyuchko, O. M., Buchatsky, L. P., Rud, Yu. P., Melezhyk, O. V. (2019). Creation of fish databases for electronic interactive map: tables and keys. Fishery sciences of Ukraine, 50 (4), 37-57. 